\title{
The Nuclear Power Plant Concept with Ball in Bowl Design
}

\author{
Eko Hidayanto $^{\mathrm{a}}$, Ainul Ibnu Khotob ${ }^{\mathrm{a} *}$, Khanif Pramusinto ${ }^{\mathrm{a}}$, Belliany Dian Asmara Hadi ${ }^{\mathrm{a}}$ \\ ${ }^{*}$ Physics Departement, Faculty of Science and Mathematics - Diponegoro University \\ Jln. Prof. H Soedharto SH., Tembalang, Semarang, 50725, Indonesia
}

\begin{abstract}
The increasing of national energy consumption urged the government to settle into renewable energy immediately (EBT) in order to fulfill national energy consumption, especially electrical energy. One of the options to fulfill the national electrical energy needed is by building a nuclear power plant (NPP). But, as one of the countries that located in Seismic Zone region of Southeast Asia, Indonesia has the most seismic activity in the world. Reviewing of Indonesia's geographical conditions that are vulnerable to earthquake and tsunami, it is necessary to make special design for nuclear power plant building. Ball in Bowl is the concept of nuclear power plant builing, with the wind flow modification system, it is useful to minimize the spread of radioactive substances released when a nuclear leak and also serves as the reactor protection system to the impacts caused by the earthquake and tsunami.
\end{abstract}

Keywords: ball in bowl; earthquake; nuclear power plant; tsunami

\section{Nomenclature}

A2 low economic growth but high population growth scenario

B2 mid economic and population growth scenario

$\mathrm{CO}_{2}$ carbon dioxide

GIS geographic information system

IPCC intergovernmental panel on climate change

WEAP water evaluation and planning software

\section{Introduction}

Energy is one of the power of the nation, the requirement for energy will ensure economic growth, resilience and independence of a nation. An increasing number of the population, living standards and economic impact on a country's are growing energy needs [1].

\footnotetext{
* Corresponding author. Tel.: +62 85268842406

E-mail address: ainulibnukhotob@st.fisika.undip.a.id
} 
According to the Law No. 17 of 2007 and Presidential Decree of 2010 on National Long-Term Development Plan 2010-2014, to contribute to the national electric energy generation and to support the national energy supply as well as considering the limited supply of fossil energy, one of the option that should be considered for fulfill electrical energy needs in Indonesia is by employing nuclear energy[2].

The system of radiation protection is given to prevent and mitigate the negative impact of radioactive substances. In the construction of nuclear power plants, radiation protection system should be prepared study materials that must be prepare carefully. The International Atomic Energy Agency (IAEA) has made the standard of radiation protection that should be in all the nuclear power plants in the world [3].

The operation of nuclear power plants are expected to give advantage and also safe for the workers and community. Due to nuclear power plant design should be prepared and planed appropriately. The operation of nuclear power plants is expected to run safe for workers, the environment and society. Planning in safety and radiation protection issues should be inherent in every stage of the planning of nuclear power plants, ranging from planning and construction to operations and decommissioning. All this is done with the goal of keeping nuclear power plants can operate safely and under control and provide maximum benefit to the nation and state of Indonesia [4].

Located in Seismic Zone region of Southeast Asia, Indonesia is the country has seismic activity and most active in the world. Surrounded by the Indo-Australian Plate and the Philippine Sea plate beneath the Eurasian plate paved, with five large islands and several peninsula, thousands of earthquakes and hundreds of tsunamis have been occurred in Indonesia over the last four hundred years [5].

Reviewing on Indonesia's geographical conditions that are vulnerable to earthquake and tsunami, it is necessary to design a special nuclear power plant construction program. It is intended as a precaution of leakage of the nuclear reactors, particularly for the case that caused by the earthquake and tsunami disaster.

\section{Methodology}

This concept was written from the analysis of nuclear leak case study and combined with a logical solution based study of literature. The purpose of this concept was to provide an alternative solution for the design of nuclear power plants, especially in Indonesia because Indonesia is a region that has a high potential for earthquake and tsunami.

\section{Results and discussion}

\subsection{Definition}

Ball in Bowl is a basin-shaped design resembles a bowl (bowl) on the surface of the soil with a nuclear reactor which is generally spherical (ball), located in the central part. This design was arranged in purpose of radiation protection devices can work effectively. Ball in Bowl design has two types of mechanisms for the protection of the reactor and spread radioactive leaks, which Wind Direction Modification and Earthquake-Tsunami Protection System. The concept of nuclear power plant with Ball in Bowl design was shown in Figure 1. 


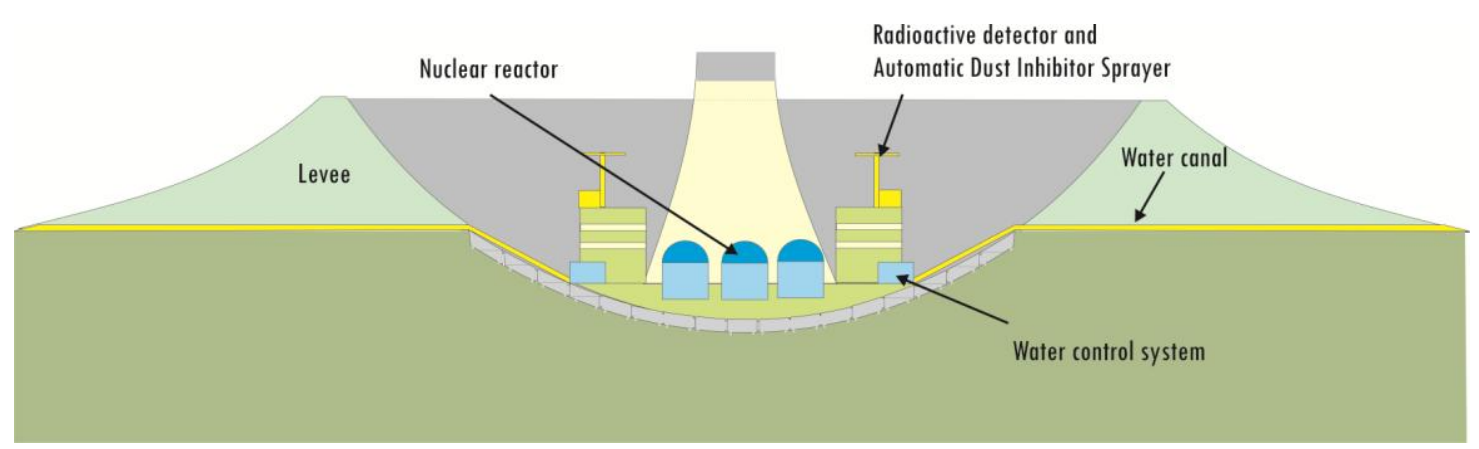

Fig. 1. The concept of nuclear power plant with Ball in Bowl design.

\subsection{Wind direction modification}

Direction and speed of wind and air stability affects the distribution pattern and Time Integrated concentration (TIC) of radioactive effluent [6]. Through wind flow modification system, it was useful to minimize the spread of radioactive substances released when the nuclear power plant reactor leaks. It was designed and be able to modify the flow of the wind around the reactor in order to prevent the wind meets a radioactive substance that can directly make increasingly wide spread of radioactive. This mechanism was shown in Figure 2.

A concave shape of the building also causes the wind flow will go down in the event of a nuclear leak. This is because when a leak occurs, the air around the reactor gets hotter than the air above it, so the air will move from top to bottom. This principle is similar as in valley and mountain breezes. Downward air flow would make dust inhibitor work effectively. This mechanism was elucidated in Figure 3.

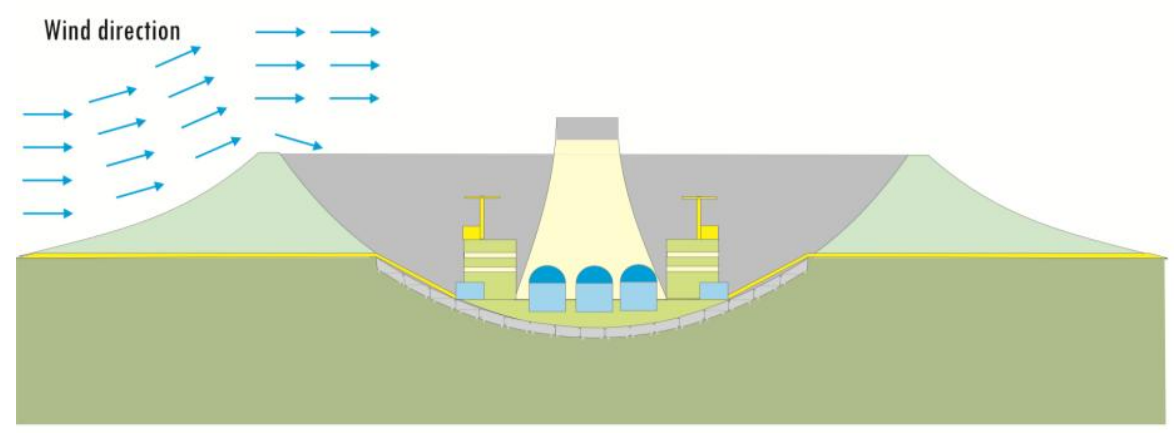

Fig. 2. Modification of wind direction scheme. 


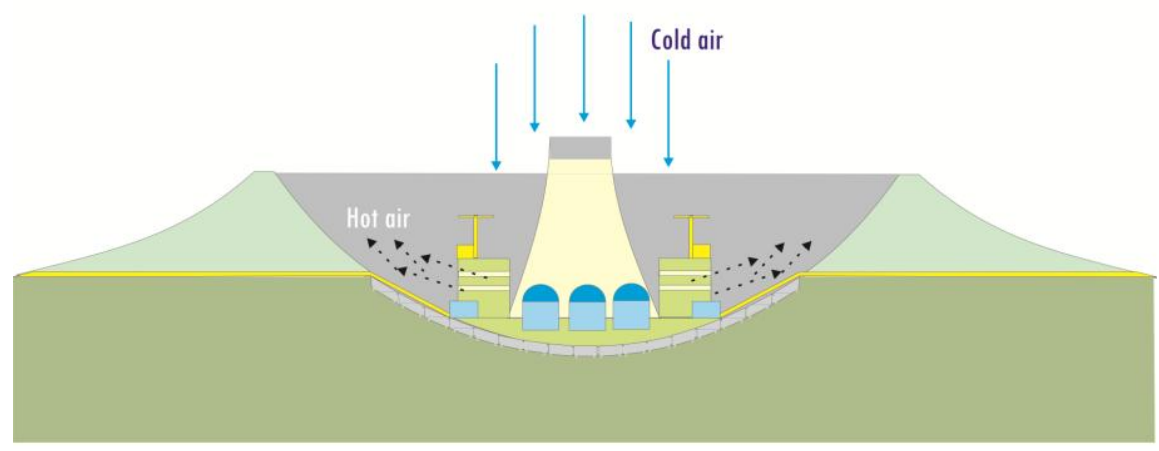

Fig. 3. Wind direction when nuclear leaks occur.

\subsection{Physical protection against earthquake and tsunami}

In terms to anticipated the damage that caused by the earthquake, the construction of earthquake-resistant buildings, design of nuclear power plants in Bowl Ball has a concrete basin system on the ground was used. The design expected will spread tremor and effectively reduce the impact of the damage caused during the earthquake. To avoid cracks and fractures on the ground floor, it can be used multiple seismic bearing system. Earthquake protection mechanism was shown in Figure 4.

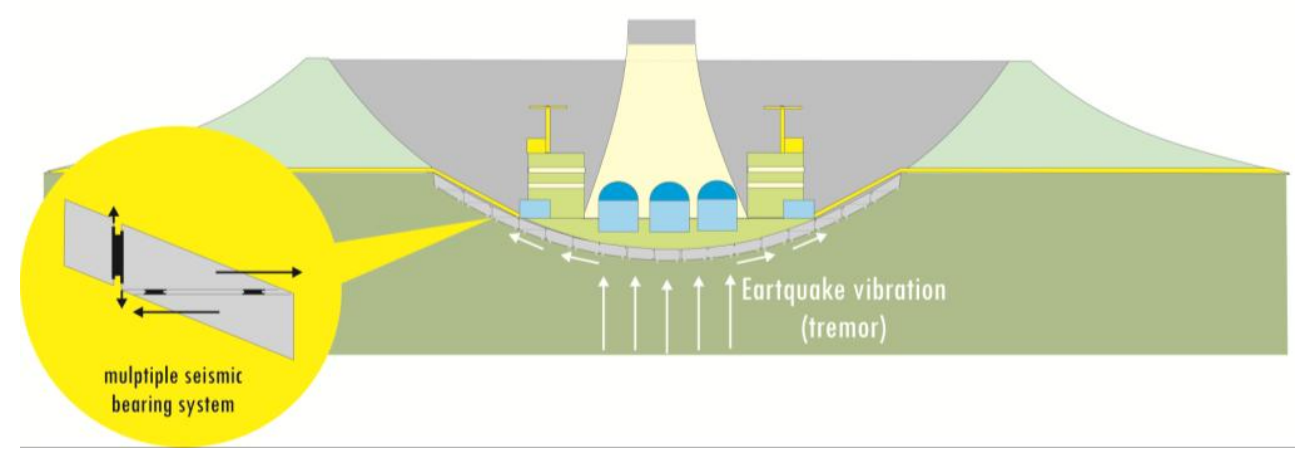

Fig. 4. Earthquake protection mechanism.

Levee system in this design is not only useful to modify the direction of the wind but also protects the NPP if hit by the tsunami. Embankment blocking function is to prevent tsunami damage the nuclear power reactors and facilities. Tsunami protection mechanism was elucidated in Figure 5. 


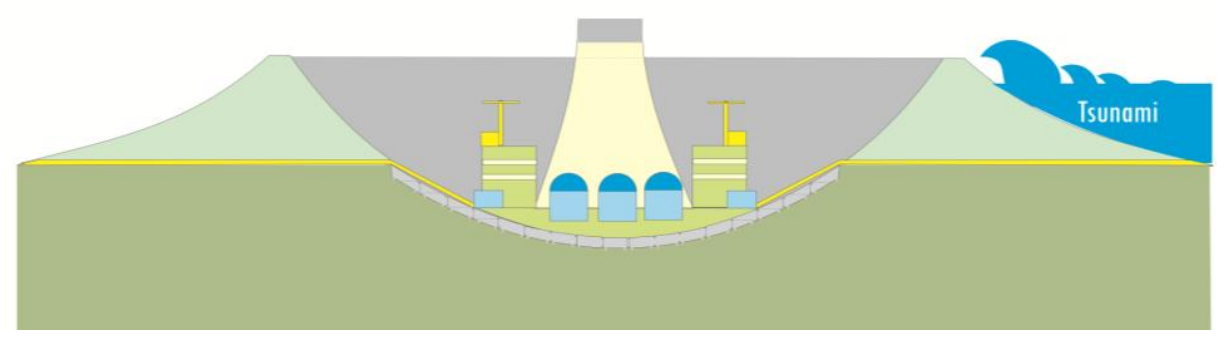

Fig. 5. Tsunami protection mechanism.

\section{Conclusion}

Ball in Bowl design is the combination of the existing protection methods with the idea of anticipating the nuclear leak and spread of radioactive. Ball in Bowl design has two types of mechanisms for the protection of the reactor and spread radioactive leaks, which Wind Direction Modification and Earthquake-Tsunami Protection System.

Based on a literature review and analysis, the concept of a nuclear reactor with Ball in Bowl design can be implemented and could potentially be the latest concepts of nuclear power plants. With the construction of nuclear power plant with Ball in Bowl design, it will be available of nuclear power plants which are not only able to fulfill national electricity needs, but also has a high protection system in case of a radiation leak caused by the earthquake and tsunami.

\section{Acknowledgement}

The authors would like to show utmost gratitude to our lecturers at Diponegoro University and our friends in Cosmos research community for the support and advices. We also should like to thank the Reviewer and the Editors have generously given up valuable time to review this paper. The success of the journal depends upon their care and competence. Their conscientiousness is much appreciated.

\section{References}

[1] Anggoro YD, Lumbanraja SM. Studi pendekatan kontrak pembangunan PLTN di Provinsi Bangka Belitung [Study on nuclear power plant construction approaches in Bangka Belitung] Prosiding Seminar Nasional ke-18 Teknologi dan Keselamatan PLTN serta Fasilitas Nuklir. Bandung: BATAN;2012. [Bahasa Indonesia]

[2] Nasrullah, M. Analisis komparasi ekonomi PLTN dan PLTU batubara untuk Bangka Belitung [Economical comparative analysis on nuclear power plant and coal power plant for Bangka Belitung]. Seminar Nasional Pengembangan Energi Nuklir IV. Jakarta: BATAN;2011. [Bahasa Indonesia]

[3] Vijayan PK, Kamble MT, Nayak A, Vaze KK, Sinha RK. Safety Features in nuclear power plants to eliminate the need emergency planning in public domain. Indian Academy of Science Journal 2013;38(2):925-943

[4] Widayati S, Andriani. Y, Elfida. Kajian awal sistem proteksi radiasi PLTN [Initial studies of radiation protection system on nuclear power plant] Prosiding Seminar Nasional Teknologi Pengelolaan Limbah VII Pusat Teknologi Limbah Radioaktif .Jakarta: BATAN;2009. [Bahasa Indonesia]

[5] Aydan O, Seismic and tsunami hazard potential in Indonesia with a special emphasis on Sumatra Island, Journal of The School of Marine Science and Technology, Tokai University 2008;6(3):19-38.

[6] Susilo YSB.Simulasi penyebaran efluen radioaktif melalui udara : studi kasus pembangkit listrik tenaga nuklir di Jepara [Simulation of the spread of airborne radioactive effluent: a case study of a nuclear power plant in Jepara] Jakarta: Universitas Indonesia;1999:2-3 [Bahasa Indonesia] 